\title{
THE RELATIONSHIP BETWEEN PROJECT MANAGEMENT OFFICE MATURITY AND ORGANISATIONAL PROJECT MANAGEMENT MATURITY: AN EMPIRICAL STUDY OF THE SOUTH AFRICAN GOVERNMENT INFRASTRUCTURE DEPARTMENTS
}

\author{
L.S. Khalema ${ }^{1}$, C.C. van Waveren ${ }^{2}$ \& K.-Y. Chan $^{3^{*}}$ \\ Department of Engineering and Technology Management \\ Graduate School of Technology Management \\ University of Pretoria, South Africa \\ ${ }^{1}$ khalemls@eskom.co.za, ${ }^{2}$ corro@up.ac.za, ${ }^{3}$ alice.chan@up.ac.za
}

\begin{abstract}
The Project Management Office (PMO) has been associated with organisational project management competence. However, there is a lack of empirical evidence to support this perception. This study examines the relationship of PMO maturity and the nine knowledge areas that describe Organisational Project Management (OPM) by collecting data from 129 PMO executives, staff, and project managers in South African Government Infrastructure Departments (SAGID) using a structured questionnaire. The results show that a PMO's 'strategic' maturity has the highest impact on all nine areas of OPM. It is thus recommended that public organisations need to accelerate the strategic maturity of their PMOs to benefit from them.
\end{abstract}

\section{OPSOMMING}

Die projekbestuurkantoor word met organisatoriese projekbestuurbevoegdheid assosieer. Daar is egter min empiriese bewysstukke om hierdie persepsie te regverdig. Die verwantskap tussen die projekbestuurkantoor volwassenheid en die nege kundigheidsareas wat organisatoriese projekbestuur volgens die Project Management Institute (PMI) beskryf, word ondersoek deur inligting van 129 projekbestuurkantoor uitvoerende beamptes, personeel en projekbestuurders in die Suid-Afrikaanse Regering se Infrastruktuur Departemente te versamel met ' $\mathrm{n}$ gestruktureerde vraelys. Die resultate wys daarop dat die projekbestuurkantoor se strategiese volwassenheid die grootste invloed op al nege die kundigheidsareas het. Dit word dus aanbeveel dat publieke organisasies die strategiese volwassenheid van hul projekbestuurkantore versnel om sodoende die meeste baat daarby te vind.

\footnotetext{
1 The author was enrolled and completed MSc (Project Management) degree in the Graduate School of Technology Management, University of Pretoria.

* Corresponding author
} 
The creation of a Project Management Office (PMO) by many organisations is still obscured by doubt and suspicion, and its value is questioned. It has been proved that establishing or having a PMO in an organisational structure is not an instant solution to project management challenges [1]. Rather, it is PMO maturity that adds value to Organisational Project Management (OPM). CPB Research found that, as the maturity of PMOs increases, so too do organisational performance and project delivery success rates [1].

The recent study of ESI International [2] emphasises the significance of the subject: "The discourse is shifting from determining PMO maturity to the value the maturing PMO brings". So the value of the maturing PMO has still to be empirically tested, and the PMO's maturity is to be correlated with either OPM maturity or project performance. The latter has already been carried out in detail [1,3]; but a direct correlation with OPM maturity is lacking. The reality is that most PMOs or corporations do not have a benchmarking measure and strategy that is aligned with developing and advancing OPM maturity [4].

The current research and literature is focused on the functions and value of PMOs in private sector corporations, and most of the studies have focused on the USA and Europe $[1,2]$. Public-sector projects face many more challenges than do private-sector projects, such as multiple stakeholders' involvement, managing an environment of constant change, and coping with constraints that include a political system, organisational stovepipes, and limited resources [5]. Moreover, the strategic objectives of the public sectors are expressed not in terms of profit but rather in terms of user satisfaction and value for a wide range of stakeholders (including politicians); so it is difficult to observe the relationship between project management implementation and Return on Investment (ROI), which is a measure often used by the private sector [6]. Due to these changing dynamics of the environment, project management is essential for helping public organisations to run projects successfully. Formal project management practices in South African public organisations are still in the development phase, while most organisations have a low maturity level [7]. Many of the project management concepts are not well formalised and/or standardised, the cost-benefit results are questioned, and there is no general consensus about the role of project management in many matrix-structured organisations [8].

Research into PMO and its influence on OPM and project performance in South Africa is limited in general. Although studies have been done in the IT industry [8], almost none have been done in the public sector, which spends billions of Rands on construction and engineering projects. So this study will close the gap in the literature, and examine the relationship between PMO maturity and OPM competence using empirical data.

The objective of this study is to establish the value that a mature PMO brings to an organisation, and whether the maturity of the PMO has any impact on OPM practice and competency. This study is undertaken for the South African Government Infrastructure Departments (SAGID) in the Gauteng Province, which is the economic heart of South Africa.

In order to achieve the above objective, the research focuses on finding solutions to the following questions:

1. Which functions of the PMO are associated with Organisational Project Management (OPM) maturity?

2. Is there evidence that increasing PMO maturity increases the maturity of OPM?

\section{THEORETICAL BACKGROUND}

The concept of a different structure being adopted by project-oriented organisations and being mandated to centralise and formalise project management processes for 'organisation-projects' strategic alignment and the successful delivery of projects is starting to impact on the South African organisational landscape. The degree of adoption varies depending on the industry; but there are no current studies that offer statistics for 
South Africa that indicate which industry is leading in the use and adoption of PMOs. Many companies have adopted a PMO to attain project management supervision, control, monitoring, support, and alignment [9]; but the true benefits, or the inherent value, have been intangible. The value and benefits of the PMO have been scrutinised and have been the subject of recent academic papers and international research reports. These have included an examination of their corresponding influence on either organisational performance or project success rate (e.g. $[6,10])$. The correlative significance of these studies and of their conclusions has also been the subject of recent academic debates. But general consensus has not yet been reached on whether the functions and value of the PMO have been successfully related to organisational or project performance. There has been one theoretical framework after another, intended to understand the PMO's value and more to the point - to identify the measurable metrics of PMO performance itself (e.g. [11]). The structure and context of the organisation in which a PMO is located has been proved to have more impact on the performance of the PMO than the characteristics of the PMO itself have [12].

Jiang and others [13], in their study of capability maturity models, mentioned that there is a direct link between process management maturity and project performance. It is in this light that the authors propose to measure OPM rather than project management competence - or project performance, which is the third variable in this chain. Therefore, by studying the correlation between PMO maturity and OPM maturity, it is assumed that project performance is directly realisable from higher OPM maturity levels. Many studies associate high performance with increased maturity in organisations [14].

It has been concluded that the act of adopting or implementing a PMO does not result in a tangible increase in performance: only the maturity of the PMO bears that fruit [1]. So assessing and benchmarking its performance is essential.

\subsection{Defining the concepts}

The Oxford English Dictionary describes 'mature' as "having reached the most advanced stage in a process". Thus 'maturity' is the condition of being mature. Phungula [15] argued that if the concept of maturity is applied to an organisation, it suggests that the organisation is in an excellent condition to achieve its strategic goals. Maturity models originate from the field of total quality management [16], where they help organisations to improve their processes and systems continually towards their future goals.

Organisations use projects as instruments for managing change [17], and project management is a traditional part of the toolkit for construction and large government projects [18]. Project management is defined as "the application of knowledge, skills, tools, and techniques to project activities to meet the project requirements" [19]. The concept of project maturity applied to organisations will also imply the effective execution of their projects. Project maturity would then mean that the organisation is ideally conditioned to deal with its projects. In 2004 the concept of 'project maturity' was integrated into the Organisational Project Management Maturity Model (OPM3) by the Project Management Institute (PMI) after it had examined 27 existing maturity models [19]. The aim of OPM3 was to integrate, assess, and improve project management practices.

Managing individual projects has evolved into a project management centre, known as a Project Management Office (PMO), an organisational unit that is responsible for supervising internal projects, and integrating competencies and resources within the organisation's line functions [20, 21]. PMO maturity will then represent the extent to which it is capable of generating value for its customers and for the organisation as a whole [22].

\subsection{PMO maturity models}

The road to PMO maturity begins with establishing the capability to create value for clients and for the whole enterprise; this is followed by implementing and enforcing those practices across all branches of the organisation. PMO maturity models in the scientific literature are limited, and few models are universally accepted standards. Most PMO 
maturity models are developed from industry by consulting professional firms with experience in the field. Examples include the PMO Maturity Cube Model, the META PMO Capability Maturity Model, the ESI PMO Maturity Model, the Panexec PMO Maturity Model, and the Manta PMO Maturity Model. Many of these have adopted an outline similar to that of the Capability Maturity Model (CMM) from Carnegie Mellon (Software Engineering Institute) with five assessed levels of maturity: Level 1 Initial, Level 2 Stable, Level 3 Defined, Level 4 Managed, and Level 5 Incorporated [23]; and a number of knowledge areas across which the practices of each level are described.

Most of these maturity models have been adopted beyond project management and have been used in PMO maturity rating; but none are sufficiently complete or relevant to be accepted by the project management community at large [23]. Top management, PMO executives, and project managers prefer to adapt and modify the models to suit their specific needs and organisational orientations.

Although there is not a generally accepted PMO maturity model, research has shown two general schools of thought: one is process-driven, and the other is business-driven [24]. The process-driven PMO is associated with the CMM, which provides a framework for systematically improving an organisation's project management competencies; whereas the business-driven PMO relates to how the PMO changes the scope of work so that it progresses from tactical to strategic, and thus provides greater business value for the organisation.

\subsection{OPM maturity models}

OPM has been traditionally defined as "the application of knowledge, skills, tools, and techniques to organisational and project activities to achieve the aims of an organisation through projects" [25]. Many businesses have added project management to their value chain as they have come to accept the competitive advantage that 'management by projects' provides in the new economic climate. Aubry and others [6] cite Dinsmore [26], who recommended a a commercial perspective on OPM through which the company is seen as a portfolio of different projects. This perspective initiated the 'corporatising' management by projects in organisations.

Benchmarking through the use of maturity models is the instrument for evaluating and determining how capable and advanced an organisation is in applying project management principles [27]. OPM maturity models serve as pointers or benchmarks for accomplishing preferred levels of competence and maturity. So they are used to evaluate where the organisation is at present, and where it wants to go in the future [4].

The Project Management Maturity Model concept has its origin in the Capability Maturity Model developed at Carnegie Mellon University in the USA between 1986 and 1993 [28]. One of the co-founders of the model describes 'process maturity' as "the extent to which a specific process is explicitly defined, managed, measured, controlled, and effective". Over the past two decades more than 30 maturity models have evolved from the capability models and have been applied in organisational process maturity; and since software development is carried out through projects, software process maturity models have evolved into a tangible way of assessing aspects of the organisation's project management maturity [16]. These models have similar structures and basic elements that define five levels of maturity. The two most influential models are Kerzner's five-level Project Management Maturity Model (K-PMMM), developed by $\mathrm{Dr}$ Harold Kerzner, a project management professional [29], and the Organisational Project Management Maturity Model (OPM3), proposed by the US Project Management Institute (PMI). Compared with K-PMMM, which is complicated and technical, OPM3 is more comprehensive, as it was the result of examining 27 existing maturity models, and it has a broad application range [30].

\section{CONCEPTUAL FRAMEWORK}

One study substantiated the relationship between project management standards and methods of project performance [10]. Thus it can be debated that delegating the project 
management standardisation role and accountability to the PMO may accomplish the objective of increased OPM competence [31]. The testing of the theoretical model below falls within the scope of this study, the emphasis being on the relationship between PMO maturity and OPM maturity, as depicted in Figure 1.

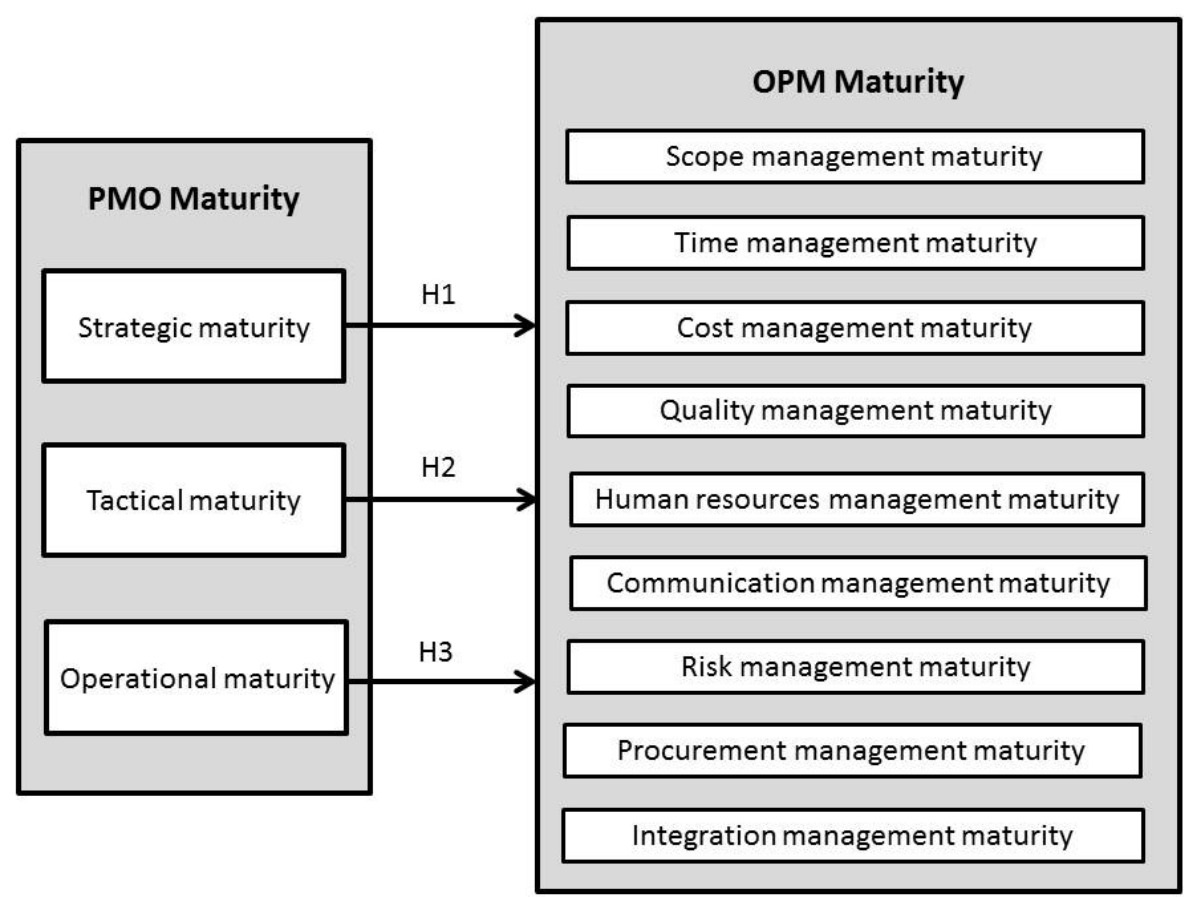

Figure 1: Research model

As indicated in Figure 1, two maturity models were used to assess both PMO maturity and OPM maturity. Both maturity models were prudently selected from the existing collection of maturity models, and carefully customised to fit the South African context without being too complex or lengthy. The models are based on a five-level ranking for maturity. The details of these two maturity models are discussed below.

The main research question interrogates the effect of PMO maturity on OPM maturity. Based on the question, three hypotheses are proposed in the research model (Figure 1):

- H1: The strategic maturity of PMO has a positive impact on the maturity of OPM in the various project management knowledge areas.

- $\quad$ H2: The tactical maturity of PMO has a positive impact on the maturity of OPM in the various project management knowledge areas.

- $\quad \mathrm{H} 3$ : The operational maturity of PMO has a positive impact on the maturity of OPM in the various project management knowledge areas.

\subsection{PMO maturity - theoretical model}

Pinto and others [22] state that recent qualitative studies (such as [32]) have indicated that "there is a degree of instability in the historical analysis of PMO". Thus they have developed a PMO maturity model and tested it for the purpose of academic discussion. This customised PMO maturity cube model - which is used in this study - summarises all the typologies and functions of the PMO in the scientific literature, and categorises them according to two principal dimensions: scope and approach [22]. 
The scope of a PMO describes the extent and latitude of the PMO's mandate, whether it is organisational, departmental, or programmatic. A PMO's approach defines the focus and objectives of the PMO - strategic, tactical, operational, or all three concurrently [22]. All the activities within the three areas were evaluated to gauge their competence and capability level in the normal course of the PMO. This establishes the extent to which the PMO is currently mature.

Using the 27 most common functions of a PMO (as identified by Hobbs and Aubry [3]), Pinto and others [22] classified them into the three approaches that an enterprise PMO (i.e. a PMO that covers the whole organisation) can operate strategically, tactically, and operationally. The next section describes these three approaches [33]:

1. At the strategic level, the role of the PMO is to ensure that projects are aligned with:

- Strategic objectives of the organisation, so that projects undertaken are in line with the long-term objectives of the business.

- Strategic growth of the organisation, so that projects undertaken will contribute positively to the growth of the business.

- Efficient and effective knowledge management, conducted to improve the policies, practices, and methodologies of project management.

2. At the tactical level, the role of the PMO is to ensure:

- Close integration between project initiatives, so that there is coordination among the various projects being undertaken by the organisation.

- Consistent quality of products and services generated by projects, by monitoring to ensure that projects closely follow the defined standards and methodologies.

- Knowledge sharing among the members of the projects to ensure clear communication between project teams.

3. At the operational level, the PMO is responsible for:

- Conducting project evaluations, by creating the process for operational reviews, approving requests for increased budgets and/or resources, and ensuring that projects are conducted in an efficient manner.

- Integration of knowledge derived from projects by ensuring that information is readily available for informed decision-making on specific implementation processes.

- $\quad$ Expert knowledge of project management, by serving as a central repository of lessons learned, best practices, and standardised methodologies.

- Constant monitoring of customer satisfaction, providing regular project status reports to decision-makers, and coordinating communications between internal and external customers.

The customised maturity model used in this study was based on the PMO Maturity Cube Model, which adopts the three approaches above. Only one enterprise scope was considered for practicality and ease of application.

The model was further customised to include five maturity levels. This was accomplished by replacing the original model's three maturity stages (basic, intermediate, and advanced) with the five maturity levels given in the Panexec PMO Capability Maturity Model depicted in Table 1.

\subsection{OPM maturity - theoretical model}

In order to customise a model that is applicable and practical for the SAGID and for the purpose of this study, a choice of similar models was required - , models that are not lengthy and that do not contain too much project management jargon. The Berkley Project Management Maturity Model, the PM Solutions Project Management Maturity Model, and Labuschagne and Marnewick's [34] Project Management Maturity Model were identified as 
Table 1: Panexec PMO Capability Maturity Model

\begin{tabular}{|c|c|c|c|}
\hline $\begin{array}{l}\text { Maturity } \\
\text { Level }\end{array}$ & Maturity & Description & Typical Manifestation \\
\hline Level 1 & $\begin{array}{l}\text { No PMO (Ad } \\
\text { hoc) }\end{array}$ & $\checkmark \quad$ PMO has not been adopted & $\begin{array}{l}\checkmark \quad \text { PM methodologies, processes \& } \\
\text { governance are random and ad } \\
\text { hoc }\end{array}$ \\
\hline Level 2 & Mobilise & $\begin{array}{l}\checkmark \quad \text { The PMO function has been } \\
\text { recognised } \\
\checkmark \quad \text { Core resources are mobilised } \\
\text { through hiring and } \\
\text { secondment within other } \\
\text { areas in the organisation }\end{array}$ & $\begin{array}{ll}\checkmark & \text { Position of PMO in the } \\
& \text { organisation and reporting } \\
& \text { lines still unclear } \\
\checkmark & \text { No re-use and repeatability } \\
\checkmark & \text { Data not reliable } \\
\checkmark & \text { No clearly-defined or } \\
& \text { documented processes } \\
\end{array}$ \\
\hline Level 3 & Design & $\begin{array}{ll}\checkmark & \text { Define/adapt clear } \\
& \text { governance framework } \\
\checkmark & \text { Develop/adapt relevant } \\
& \text { methodology } \\
\checkmark & \text { Design and document core } \\
\text { processes, project } \\
\text { management product, and } \\
\text { artefacts }\end{array}$ & 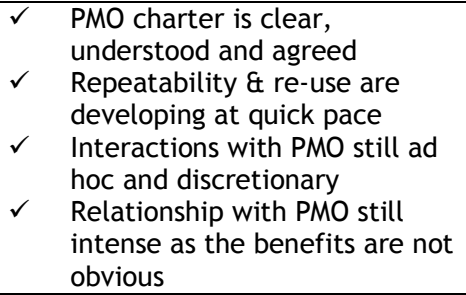 \\
\hline Level 4 & Implement & $\begin{array}{l}\text { Rollout of governance, } \\
\text { methodologies and } \\
\text { processes in all initiatives, } \\
\text { projects and programmes } \\
\text { Establish PMO in a broader } \\
\text { organisation } \\
\text { Build relevant capabilities } \\
\text { and communities of practice } \\
\text { in and out of PMO }\end{array}$ & $\begin{array}{l}\checkmark \quad \text { There is consistency and } \\
\text { homogeneity coming in \& out } \\
\text { of PMO, resulting in reliable } \\
\text { data to create a single source } \\
\text { of truth } \\
\checkmark \quad \begin{array}{l}\text { Some PMO aspects may be } \\
\text { perceived as 'rigid' }\end{array}\end{array}$ \\
\hline Level 5 & Manage & $\begin{array}{ll}\checkmark & \text { Identify, plan and } \\
\text { implement improvements } \\
\checkmark \quad \text { Manage cultural change }\end{array}$ & $\begin{array}{l}\checkmark \quad \text { PMO is recognised as a change } \\
\text { agent and model across the } \\
\text { broader organisation } \\
\checkmark \quad \text { The values and functions of the } \\
\text { PMO are deeply embedded in } \\
\text { the organisation }\end{array}$ \\
\hline
\end{tabular}

less extensive because of their ease of application, methodology, and number of questions. The generic model was used to measure the maturity of the processes contained in the nine knowledge areas of the PMBoK Guide. Thus a modified questionnaire was developed out of these three models and used for the purpose of this paper.

A few models were disregarded since they entail a more detailed and complex questionnaire, supplemented with interviews, in order to reach any conclusive results. For example, the Organisational Project Management Maturity Model requires 151 questions that identify three levels of assessment, project, programme, and portfolio management [35].

\section{RESEARCH DESIGN AND METHODOLOGY}

A quantitative research strategy was more suitable than a qualitative research strategy for this research. Since the focus of the study is on proving a correlation between multiple variables, a quantitative study, given its investigative and exploratory nature based on statistical analysis, was suitable for this research.

A questionnaire comprising 50 customised questions was designed as a survey tool. Selected questions were taken from established maturity models to evaluate the perceived maturity levels for both PMO and OPM without deterring the respondents or risking a very low 
Table 2: PMO \& OPM maturity research methodology

\begin{tabular}{|c|c|c|c|c|}
\hline TARGETED INDUSTRY & $\begin{array}{c}\text { VARIABLES } \\
\text { AND } \\
\text { FACTORS }\end{array}$ & $\begin{array}{c}\text { DATA } \\
\text { COLLECTION } \\
\text { METHOD }\end{array}$ & $\begin{array}{c}\text { DATA } \\
\text { ANALYSIS } \\
\text { METHOD }\end{array}$ & CONTRIBUTIONS \\
\hline $\begin{array}{c}\text { Construction \& } \\
\text { engineering } \\
\begin{array}{c}\text { infrastructure - SA } \\
\text { public sector } \\
\text { organisations }\end{array}\end{array}$ & $\begin{array}{c}\text { Maturity } \\
- \text { OPM }\end{array}$ & $\begin{array}{c}\text { Survey } \\
\text { Maturity }\end{array}$ & $\begin{array}{c}\text { - Descriptive } \\
\text { statistics } \\
- \text { Correlation } \\
\text { analysis } \\
\text { - Regression } \\
\text { analysis }\end{array}$ & $\begin{array}{c}\text { - PMO functions } \\
\text { driving OPM } \\
\text { - Relationship } \\
\text { between PMO Maturity } \\
\text { and OPM Maturity }\end{array}$ \\
\hline
\end{tabular}

response rate. Answers were based on a 1 to 5 Likert scale, where 1 referred to 'strongly disagree' and 5 referred to 'strongly agree'.

Owing to the precise nature of the research topic, the population sample consisted of SAGID staff involved in infrastructure projects and programmes in the Gauteng Province of South Africa, and restricted to the fields of construction and engineering. The respondents were not individually selected: the questionnaires were sent to relevant project staff after ensuring that they had intimate knowledge of both the PMO and the OPM body of knowledge.

\subsection{Sampling method}

An invitation to take part in a web-based survey was sent to the mailing list of the SA Government Infrastructure Departments (PMO staff and project managers) - a total of 860 people in Gauteng Province. Of that number, 186 responded. This will be referred to as the 'self-selected' population sample. Of the 186 responses, 58 were eliminated from the survey results for incompleteness. Thus 128 responses were used.

\subsection{Data analysis techniques}

Statistical analysis entailed examining data to interpret its meaning, to make generalisations, and to extrapolate trends [15]. The data was analysed with the use of the statistical package SPSS. The following tests were chosen to be carried out on the data:

1. Descriptive statistics to define the population sample's profile.

2. Reliability evaluation of the items used in the questionnaire.

3. Correlation analysis to explore the relationship between PMO and OPM.

4. Regression analysis to explore the predictive power of PMO on OPM.

\section{RESULTS}

\subsection{Descriptive statistics: Demographic information}

The descriptive statistics for the sample are summarised in Table 3 on the next page.

The majority of the respondents came from public enterprise (parastatal) organisations. As can be seen from Figure 2, they make up $43 \%$ of the respondents, followed by Government agencies/utilities at $22 \%$. The majority were uncertified project managers: as can be seen from Figure 3, they make up $49 \%$ of the respondents, followed by PMO staff at $17 \%$. The project managers who are registered with either SACPCMP or PMP make up 13\% of the respondents.

The majority of the respondents had 1-5 years of work experience in their current positions, and make up $48 \%$ of the respondents, followed by $32 \%$ who fall in the range $6-10$ years' working experience in their current positions.

The majority of the PMOs had been adopted in the previous five years, mostly in public infrastructure organisations, followed by $19 \%$ of the organisations whose PMOs were in the range of 6-10 years. 
Table 3: Demographic statistics

\begin{tabular}{|c|c|c|}
\hline Demographic information & Items & $\begin{array}{l}\text { Frequency } \\
\text { count }\end{array}$ \\
\hline \multirow[t]{5}{*}{ Government structure } & Parastatal & $53.1 \%$ \\
\hline & National & $11.4 \%$ \\
\hline & Provincial & $6.3 \%$ \\
\hline & Municipalities & $7.4 \%$ \\
\hline & Utilities/Agencies & $21.7 \%$ \\
\hline \multirow[t]{5}{*}{ Respondents' job title } & $\begin{array}{lll}\begin{array}{l}\text { Project } \\
\text { certified) }\end{array} & \text { manager } & \text { (not } \\
\end{array}$ & $49 \%$ \\
\hline & Project manager (certified) & $13 \%$ \\
\hline & PMO executive & $6 \%$ \\
\hline & PMO staff & $17 \%$ \\
\hline & $\begin{array}{l}\text { Programme/Portfolio } \\
\text { manager }\end{array}$ & $15 \%$ \\
\hline \multirow{5}{*}{$\begin{array}{l}\text { Respondents' years of experience in current } \\
\text { position }\end{array}$} & 0 to 5 years & \\
\hline & 6 to 10 years & $48 \%$ \\
\hline & 11 to 15 years & $32 \%$ \\
\hline & 16 to 20 years & $10 \%$ \\
\hline & 21 years and above & $6 \%$ \\
\hline \multirow[t]{5}{*}{ Age of PMO } & 1 to 5 years & $42 \%$ \\
\hline & 6 to 10 years & $19 \%$ \\
\hline & 11 to 15 years & $10 \%$ \\
\hline & 16 to 20 years & $17 \%$ \\
\hline & Not sure & $12 \%$ \\
\hline \multirow[t]{2}{*}{ Existence of PMO } & Organisation with PMO & $83 \%$ \\
\hline & Organisation without PMO & $17 \%$ \\
\hline
\end{tabular}

About $83 \%$ of the public infrastructure organisations confirmed that they had some kind of project office structure. The names of these structures included Project Management Unit (PMU), Project Support Office (PSO), Project Office (PO), Project Management Office (PMO), and Enterprise Programme Management Office (EPMO).

\subsection{Reliability \& factor analysis}

Cronbach's a evaluates the internal consistency of questions in a questionnaire that are used to represent a theoretical construct of a variable. The values are shown in Table 4 on the next page.

The Cronbach a-values ranged from 0.806 for project procurement management maturity to 0.933 for PMO tactical maturity. Thus all of the values were above the minimum threshold of 0.70 , suggesting a relatively high internal consistency of the questions. In addition to the reliability test, factor analysis was performed to identify and classify the fundamental variables, or factors, that account for the correlation trend within a set of identified variables. Thus the factor analytic procedure was to test whether the survey instrument's questions under each variable measured the same construct. All individual variables in the questionnaire were tested, and were found to measure the same construct, except for IV2 and DV9. The independent variable IV2 (PMO tactical assessment) resulted in two separate components:

- Methodological tactical assessment

(IV2.1)

- HR/training tactical assessment

The dependent variable DV9 (OPM integration management assessment) resulted in two separate components: 
Table 4: Cronbach's a-values for all variables

\begin{tabular}{|c|c|c|c|}
\hline Variables & Code & $\begin{array}{c}\text { Cronbach's } \\
\text { a-values }\end{array}$ & No. of items \\
\hline \multicolumn{4}{|l|}{ Three PMO functions: } \\
\hline PMO Strategic Maturity Assessment & IV1 & 0.881 & 8 \\
\hline PMO Tactical Maturity Assessment & IV2 & 0.933 & 14 \\
\hline PMO Operational Maturity Assessment & IV3 & 0.903 & 10 \\
\hline \multicolumn{4}{|l|}{ Nine project management knowledge areas: } \\
\hline Scope Management Maturity Assessment & DV1 & 0.831 & 3 \\
\hline Time Management Maturity Assessment & DV2 & 0.847 & 3 \\
\hline Cost Management Maturity Assessment & DV3 & 0.854 & 3 \\
\hline Quality Management Maturity Assessment & DV4 & 0.841 & 3 \\
\hline Human Resources Management Maturity Assessment & DV5 & 0.895 & 6 \\
\hline Communications Management Maturity Assessment & DV6 & 0.848 & 4 \\
\hline Risk Management Maturity Assessment & DV7 & 0.904 & 3 \\
\hline Procurement Management Maturity Assessment & DV8 & 0.806 & 2 \\
\hline Integration Management Maturity Assessment & DV9 & 0.926 & 13 \\
\hline
\end{tabular}

- High-level integration management assessment (DV9.1)

- $\quad$ Lower-level integration management assessment (DV9.2)

This increased the total number of independent variables (IVs) to four and independent variables (DVs) to ten.

\subsection{Means and standard deviations}

The means and standard deviations of the variables in the research model are shown in Table 5.

According to the five assessed levels of maturity (Level 1 Initial, Level 2 Stable, Level 3 Defined, Level 4 Managed, Level 5 Incorporated [23]), the PMO and OPM maturity levels are at the 'Defined' level where initial integration is taking place.

\subsection{Correlation results}

Pearson correlation coefficients for the four independent variables describing the PMO maturity assessment and for the 10 dependent variables describing the OPM maturity assessment were calculated. SPSS was used to calculate and illustrate the p-values to substantiate whether the results are statistically significant.

The maturity of each PMO function was assessed as a separate variable, and each variable's association with the nine project management areas was tested through correlation studies. This resulted in the following weak but positive and significant correlations:

1. PMO strategic maturity (IV1) has positive correlation (thus is positively associated with) all nine project management knowledge area maturities.

2. PMO methodological tactical maturity (IV2.1) is positively associated with only seven project management area maturities, thus excluding project cost management (DV3), project communications management (DV6), and low-level project integration management (IV9.2) variables.

3. PMO HR/training tactical maturity (IV2.2) is positively associated with only five project management area maturities, thus excluding project cost management (DV3), project quality management (DV4), risk management (DV7), project procurement management (DV8), and high-level project integration management (DV9.1) variables. 
Table 5: Means and standard deviations

\begin{tabular}{|l|c|c|c|}
\hline Variables & Code & Mean & $\begin{array}{c}\text { Standard } \\
\text { Deviation }\end{array}$ \\
\hline PMO Strategic Maturity Assessment & IV1 & 3.48 & 0.76 \\
\hline PMO Tactical Maturity Assessment & IV2 & 3.46 & 0.82 \\
\hline PMO Operational Maturity Assessment & IV3 & 3.46 & 0.83 \\
\hline Scope Management Maturity Assessment & DV1 & 3.6 & 0.88 \\
\hline Time Management Maturity Assessment & DV2 & 3.19 & 1.03 \\
\hline Cost Management Maturity Assessment & DV3 & 3.31 & 0.95 \\
\hline Quality Management Maturity Assessment & DV4 & 3.48 & 0.87 \\
\hline $\begin{array}{l}\text { Human Resources Management Maturity } \\
\text { Assessment }\end{array}$ & DV5 & 3.40 & 0.81 \\
\hline $\begin{array}{l}\text { Communications Management Maturity } \\
\text { Assessment }\end{array}$ & DV6 & 3.5 & 0.86 \\
\hline Risk Management Maturity Assessment & DV7 & 3.52 & 0.94 \\
\hline $\begin{array}{l}\text { Procurement Management Maturity } \\
\text { Assessment }\end{array}$ & DV8 & 3.75 & 0.96 \\
\hline $\begin{array}{l}\text { Integration Management Maturity } \\
\text { Assessment }\end{array}$ & DV9 & 3.48 & 0.77 \\
\hline
\end{tabular}

Table 6: Pearson correlation coefficients matrix

\begin{tabular}{|c|c|c|c|c|c|c|c|c|c|c|c|}
\hline \multirow{2}{*}{\multicolumn{2}{|c|}{$\begin{array}{l}\text { Pearson } \\
\text { correlation } \\
\text { coefficients }\end{array}$}} & \multicolumn{10}{|c|}{ Project management knowledge areas } \\
\hline & & DV1 & DV2 & DV3 & DV4 & DV5 & DV6 & DV7 & DV8 & DV9.1 & DV9.2 \\
\hline \multirow{4}{*}{ 임 } & IV1 & $0.379^{*}$ & $0.308^{*}$ & $0.328^{*}$ & $0.379^{*}$ & $0.360^{*}$ & $0.356^{*}$ & $0.305^{*}$ & $0.347^{*}$ & $0.389^{*}$ & $0.317^{*}$ \\
\hline & IV2.1 & $0.302^{*}$ & $0.240^{*}$ & 0.178 & $0.273^{*}$ & $0.223^{*}$ & 0.130 & $0.266^{*}$ & $0.350^{*}$ & $0.382^{*}$ & 0.187 \\
\hline & IV2.2 & $0.211^{*}$ & $0.219^{*}$ & 0.183 & 0.181 & $0.236^{*}$ & $0.317^{*}$ & 0.199 & 0.005 & 0.087 & $0.339^{*}$ \\
\hline & IV3 & $0.290^{*}$ & $0.263^{*}$ & $0.359^{*}$ & $0.307^{*}$ & 0.194 & $0.291^{*}$ & $0.298^{*}$ & $0.205^{*}$ & $0.310^{*}$ & $0.310^{*}$ \\
\hline
\end{tabular}

4. PMO operational maturity (IV3) is positively associated with eight project management area maturities, thus excluding the project human resources management variable (DV5), but including both project integration management variables (DV $9.1 \&$ DV 9.2).

\subsection{Multivariate regression results}

One of the aims of this research was to assess the maturity of PMO in the SAGID and to identify the best predictors of OPM maturity from the variables describing PMO maturity. Multivariate regression models are tested:

$$
D V=B_{0}+B_{1}(I V 1)+B_{2}(I V 2.1)+B_{3}(I V 2.2)+B_{4}(I V 3)
$$

The dependent variable (DV) in the above equation is the OPM's maturity in the various project management knowledge areas. The four independent variables (IV) are the four PMO maturity approaches. In order to test $\mathrm{H} 1, \mathrm{H} 2$, and $\mathrm{H} 3$, the regression beta coefficients (B) will indicate whether or not the IV has a significant positive/negative impact on the chosen DV.

The final and best regression model of four regression models indicated only one predictor with the highest statistical significance. The regression coefficients are reported in Table 4. It is in this regard that the study concludes that the variable with the highest predictive power is PMO strategic maturity, which accounts for $12.1 \%$ of the variance in project quality management maturity $(B=0.354, p<0.01)$ and project integration management 
$(B=0.355, p<0.01)$. PMO strategic maturity also accounts for $11.9 \%$ of the variance in project communications management $(B=0.351, p<0.01)$, followed by project scope management $(B=0.342, p<0.01)$, project human resources management $(B=0.341, p<0.01)$, project integration management $(B=0.326, p<0.01)$, project time management $(B=0.321, p<0.01)$, project risk management $(B=0.304, p<0.01)$, and finally project cost management $(B=0.276$, $\mathrm{p}<0.01$ ), as shown in Table 7 below.

Table 7: Regression results - The best predictors of OPM maturity from the variables

\begin{tabular}{|l|c|c|c|c|c|}
\hline & $\begin{array}{c}\% \\
\text { Variation }\end{array}$ & $\begin{array}{c}\text { IV1 - PMO } \\
\text { strategic } \\
\text { maturity }\end{array}$ & $\begin{array}{c}\text { IV2.1 - PMO } \\
\text { method- } \\
\text { logical } \\
\text { tactical } \\
\text { maturity }\end{array}$ & $\begin{array}{c}\text { IV2.2 - PMO } \\
\text { HR/training } \\
\text { tactical } \\
\text { maturity }\end{array}$ & $\begin{array}{c}\text { IV3 - } \\
\text { PMO } \\
\text { operational } \\
\text { maturity }\end{array}$ \\
\hline $\begin{array}{l}\text { DV1 - scope } \\
\text { management }\end{array}$ & $11.2 \%$ & $0.342^{* * *}$ & & & \\
\hline $\begin{array}{l}\text { DV2 - time } \\
\text { management }\end{array}$ & $9.9 \%$ & $0.321^{* * *}$ & & & $0.467^{*}$ \\
\hline $\begin{array}{l}\text { DV3 - cost } \\
\text { management }\end{array}$ & $7.2 \%$ & $0.276^{* *}$ & & \\
\hline $\begin{array}{l}\text { DV4 - quality } \\
\text { management }\end{array}$ & $12.1 \%$ & $0.354^{* * *}$ & & $0.366^{*}$ & $-0.535^{* *}$ \\
\hline $\begin{array}{l}\text { DV5 - HR } \\
\text { management }\end{array}$ & $11.2 \%$ & $0.341^{* * *}$ & & & \\
\hline $\begin{array}{l}\text { DV6 - } \\
\text { communications } \\
\text { management }\end{array}$ & $11.9 \%$ & $0.351^{* * *}$ & & & \\
\hline $\begin{array}{l}\text { DV7 - risk } \\
\text { management }\end{array}$ & $8.9 \%$ & $0.304^{* *}$ & & $-0.273^{*}$ & \\
\hline $\begin{array}{l}\text { DV8 - procurement } \\
\text { management }\end{array}$ & $11.1 \%$ & $0.340^{* * *}$ & & & \\
\hline $\begin{array}{l}\text { DV9.1 - high level } \\
\text { integration } \\
\text { management }\end{array}$ & $12.1 \%$ & $0.355^{* * *}$ & & & \\
\hline $\begin{array}{l}\text { DV9.2 - low level } \\
\text { integration } \\
\text { management }\end{array}$ & $10.2 \%$ & $0.326^{* * *}$ & & & \\
\hline
\end{tabular}

PMO tactical maturity (IV2.2) has a significant and negative B-value of $-0.273(p<0.10)$, and accounts for $5.9 \%$ of the variance in project procurement management. PMO operational maturity (IV3) has a significant and positive $B$-value of $0.467(\mathrm{p}<0.1)$, and accounts for $4.8 \%$ of the variance in project cost management. PMO operational maturity (IV3) also has a significant and negative $B$-value of $-0.535(\mathrm{p}<0.05)$, and accounts for $6.2 \%$ of the variance in project human resources management.

\section{CONCLUSIONS AND RECOMMENDATIONS}

\subsection{Conclusions}

This study involved two areas of research:

a. Which functions of the PMO are associated with Organisational Project Management (OPM) maturity?

b. Is there evidence that increasing PMO maturity increases the maturity of OPM?

To respond to the questions using the correlation and regression statistical models, the questions were translated into the following hypotheses:

- $\quad \mathrm{H} 1$ : The strategic maturity of PMO has a positive impact on the maturity of OPM in the various project management knowledge areas. 
The research confirmed this hypothesis: there is a positive relationship between PMO strategic maturity and nine variables of OPM maturity. PMO strategic maturity does positively influence project management maturity in all nine project management variables.

- $\quad \mathrm{H} 2$ : The tactical maturity of PMO has a positive impact on the maturity of OPM in the various project management knowledge areas.

Only one aspect (HR/training) of PMO tactical maturity indicated a weak (significant at $\mathrm{p}<0.1)$ and positive relationship with human resources management, but showed a weak and negative relationship with project procurement management. Thus hypothesis $\mathrm{H} 2$ was not supported by this research.

- $\quad \mathrm{H} 3$ : The operational maturity of PMO has a positive impact on the maturity of OPM in the various project management knowledge areas.

PMO operational maturity showed a weak relationship with project cost management and project human resources (HR) management. Thus hypothesis H3 was not supported.

\subsection{Recommendations}

All indications suggest that South African public organisations are heading towards higher PMO maturity. From the research findings, a wide spectrum of recommendations to maintain and continue improving PMO maturity in the SAGID in Gauteng can be made:

1. The implementation, age, and presence of a PMO do not translate into OPM competence and maturity. The PMO has to be mature to realise any benefits. Public organisations need to accelerate the strategic maturity of their PMOs to benefit from them.

2. Of the three PMO functions, only strategic maturity has a strong and positive impact on the OPM's maturity in all nine knowledge areas. As projects become more complex, they are generally more strategic in nature. It is important that PMO is able to perform its strategic function where it translates particular project knowledge into the management of multiple projects, and then into strategic organisational goals [36].

These recommendations to maintain and continue improving organisational project management (OPM) maturity in the SAGID can also be made:

1. Public organisations in SA need to assess their project management capabilities to benchmark the OPM's and the projects' performance against international standards and among competitors. This is the only way to ensure higher performance.

2. Public organisations in SA need to focus on achieving ISO 9001 certification, as it will assist in streamlining and formalising standard methodologies and project management processes.

\subsection{Contributions to knowledge}

This study embodies a determination to make considerable improvements to the insufficient body of knowledge about PMO roles, scope, and competencies in the project management fraternity of SA, especially in public organisations managing construction and engineering projects. As Kwak and Dai [37] say, "this research is intended to provide invaluable information for those operating, expanding or considering PMO in its advanced project management practice". By investigating the relationship between PMO maturity and project management maturity, the top management and policy-makers in public enterprises (parastatals) and in local government (municipalities) can decide either to create or to mature PMOs in their infrastructure organisations. 


\section{REFERENCES}

[1] CBP Research 2007. State of the PMO 2007-2008. Havertown. PA: Taylor \& Francis Group.

[2] ESI International. 2011. The global state of the PMO: Its value, effectiveness and role as the hub of training. Arlington. VA: ESI International.

[3] Hobbs, B. \& Aubry, M. 2007. A multi-phase research program investigating project management office. Project Management Journal, 38(1), pp 74-86.

[4] Keating, D. 2009. How does project management office (PMO) deliver value to organisations? Galway: National University of Ireland.

[5] Wirick, D.W. 2009. Public-sector project management: Meeting the challenges and achieving results. Hoboken. New Jersey: Wiley \& Sons Inc.

[6] Aubry, M., Richer, M.-L., Lavoie-Tremblay, M. \& Cyr, G. 2011. Pluralism in PMO performance: the case of a PMO dedicated to a major organisational transformation. Project Management Journal, 42(6), pp 60- 77.

[7] Rwelamila, P. 2007. Project management competence in public sector infrastructure organisations. Construction Management and Economics, 25(1), pp 55-66.

[8] Martin, M. 2007. Establishing the benefits of implementing an IT project management office (PMO) in Nelson Mandela Metropolitan area. Port Elizabeth: Nelson Mandela Metropolitan University.

[9] Hill, G. 2004. Evolving the project management office: The competency continuum. Information Systems Management Journal, 21(4), pp 45-51.

[10] Dai, C.X. \& Wells, W.G. 2004. An exploration of project management office features and their relationship to project performance. International Journal of Project Management, 22(7), pp 523-532.

[11] Hurt, M. \& Thomas, J.L. 2009. Building value through sustainable project management office. Project Management Journal, 40(1), pp 55-72.

[12] Hobbs, B. \& Aubry, M. 2010. What really affects the performance of the PMOs, 10th EURAM Conference, Tor Vergata university, Rome, Italy.

[13] Jiang, J.J., Klein, G., Hwang, H.-G., Huang J. \& Hung, S.-Y. 2004. An exploration of the relationship between software development process maturity and project performance. Information \& Management, 41(3), pp 279-288.

[14] Hartman, F. \& Ashrafi, R. 2004. Development of the SMART project planning framework. International Journal of Project Management, 22(6), pp 499-510.

[15] Phungula, M. 2008. Review and analysis of organisational project management maturity of the South African Government departments involved in public private partnership (PPP). Pretoria: UNISA.

[16] Cooke-Davies, T. \& Arzymanov, A. 2003. The maturity of project management in different industries: An investigation into variations between project management models. International Journal of Project Management, 21, pp 471-478.

[17] Balck, H. 1990. Projects as a form of change, pp 22-28 in R. Gareis, ed., Handbook of Management by Projects. Vienna: MANZshe Verlag.

[18] Crawford, J.K. 2002. The strategic project office: A guide to improving organizational performance. Boca Raton, FL: CRC Press.

[19] PMI Project Management Institute. 2008. A guide to the project management body of knowledge (PMBOK Guide), 4th ed. Newtown Square, PA: Author.

[20] Stroe, A. 2012. An analysis on the maturity of the project management office. University of Utrecht, NL: Masters thesis.

[21] Martins, V.A. \& Martins, M.R. 2012. Outsourcing operations in project management offices: The reality of Brazilian companies. Project Management Journal, 43(2), pp 68-83.

[22] Pinto, A., Cota, M. \& Levin, G. 2010. The PMO maturity cube, a project management office maturity. US: PMI.

[23] Bohner, S. 2000. PMOs: Projects in harmony. Washinton: Gantthead.

[24] Woerner, B. 2006. Growing up: The information technology project management office (PMO)'s journey from infancy to maturity, in Seattle, Washington: PMI Global Congress Proceedings.

[25] Fahrenkrog, S., Abrams, F., Haeck W. \& Whelbourn, D. 2003. Project Management Institute's

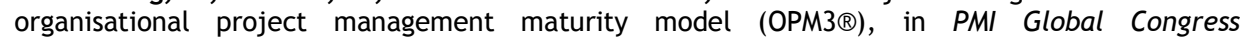
Proceedings. Baltimore: PMI.

[26] Dinsmore, P. 1996. Toward corporate project management: Beefing up the bottom line with MOBP. PM Network, June, pp 9-11.

[27] Russel, J. 2006. Improving GIS project management by use of the project management maturity models and other structured methods. Manchester: Manchester Metropolitan University.

[28] Paulk, M., Curtis, B., Chrissismb, B. \& Weber, C. 1993. Capability maturity model for software. Pittsburgh: Carnegie Mellon University.

[29] Kerzner, H. 2001. Strategic planning for project management using a project management maturity model. NY: John Wiley \& Sons. 
[30] Yang, X. \& Wang, X. 2009. Study on the management maturity model of high-tech venturing project based on fuzzy comprehensive evaluation, in Second International Conference on Future Information Technology and management Engineering, IEEE.

[31] Gorshkova, E. 2011. Improving project management capability with assistance of PMO in a technology, Goteborg. Sweden: Chalmers University of Technology.

[32] Aubry, M., Hobbs, B. \& Thuillier, D. 2008. Organisational project management: An historical approach to the study of PMOs. International Journal of Project Management, 26(1), pp 38-43.

[33] Desouza, K.C. \& Evaristo, J.R. 2006. Project management offices: A case of knowledge-based archetypes. International Journal of Information Management, 26(7), pp 414-423.

[34] Labuschagne, L. \& Marnewick, C. 2009. Prosperus Report 2008: IT project management maturity vs. project success in SA. Johannesburg, SA: PMISA.

[35] Al-Ahmad, A. 2009. Evaluation of project management maturity: The role of organization Influences in the GCC countries. Lille, France: ESC-Lille University.

[36] Thiry, M. \& Deguire, M. 2007. Recent developments in project-based organisations. International Journal of Project Management, 25(7), pp 649-658.

[37] Kwak, Y. \& Dai, C. 2000. Assessing the value of project management offices (PMO), in PMI Research Conference. USA: PMI. 